\title{
Povinnosti správních orgánů ve vztahu k procesním právům účastníků správního řízení v procesu dokazování
}

\author{
Obligations of the Administrative Authorities in Relation \\ to the Procedural Rights of Parties to the Administrative \\ Procedure in the Process of Evidence
}

\author{
Alena Kliková*
}

\begin{abstract}
Abstrakt
Predkládaná stat" je vènována problematice povinnosti správnich orgánu v procesu správího dokazováni a je-

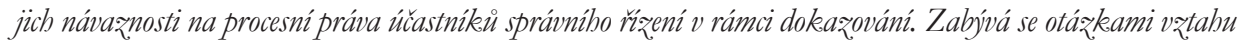
porušeni povinností správnich orgámi a omezení procesnich práv účastníkì. Jednotlivé povinnosti správních orgáni budou vysvétleny a vymezeny jak z pobledu správního orgánu, tak ve və̨tabu k procesním práviom úăastníka. Reséena je také otázka, zda jednotlivé povinnosti správního orgánu v procesu dokazováni vytvárí s procesnimi práyy ǘastnike určité dvojice, které musi spolu plně korespondovat, nebo żda mohou pisobit samostatně. Pozornost je zamèrena rovnèž ze shora uvedených úbli pobledu také na aktuálni otázky vatabujici se k institutu dokazováni ve správnim rǐzení. Vedle správnèprávního př̌stupu bude žáasti uplatnèn také prǐstup správnèvédni, zamèrený na efektivnost prǐslušné právni úpravy, resp. její pissobení v praxi správnich orgámu.
\end{abstract}

Klíčová slova

Správin rád; správni ř̌zení; práva účastnikui; povinnosti správních orgámi; dokazování.

\section{Abstract}

The present paper deals with issues related to the obligations of the administrative bodies in the process of administrative evidence and their relation to the procedural rights of the participants in the administrative proceedings within evidence. It deals with relation of the breach of obligations of the administrative bodies and limitation of the procedural rights of the participants. Individual obligations of the administrative bodies are explained and defined both from the point of view of the administrative body and in relation to the procedural rights of the participant. Attention is also focused on the questions whether the individual duties of an administrative body in the evidence process create certain pairs that must fully correspond with the procedural rights of the participant or whether these institutions can exist separately. The contribution seeks to provide answers to a number of questions that may arise in connection with these duties and rights. It focuses on current legal issues related to evidencing in the administrative procedure, precisely in connection with the procedural rights of the participants and the corresponding duties of the administrative authorities.

\footnotetext{
* JUDr. Alena Kliková, Ph.D., Katedra správní vědy a správního práva, Právnická fakulta, Masarykova univerzita, Brno / Department of Administrative Studies and Administrative Law, Faculty of Law, Masaryk University, Brno, Czech Republic / E-mail: alena.klikova@law.muni.cz / ORCID: 0000-0002-1233-9170

1 Tento článek byl vypracován v rámci projektu Grantové agentury České republiky č. GA13-30730S „Prostrédky ochrany subjeketivních práv ve verégné správě, jejich systém a efeketivnost".
} 


\section{Keywords}

Administrative Procedure; Administrative Procedure; Rights of Participants; Obligations of Administrative Bodies; Evidence.

\section{Úvod}

Předkládaný článek si klade za cíl vymezit a zhodnotit zákonem stanovené povinnosti správních orgánů vưči účastníkům, a to v procesu dokazování ve správním řízení. Jednotlivé povinnosti správních orgánů korespondují s právy účastníků, která nesmí být v rámci správního řízení porušována. Bude učiněn pokus analyticky zhodnotit efektivnost jednotlivých zákonných povinností správních orgánů spojených s dokazováním př̀ uplatňování a ochraně veřejných subjektivních práv jednotlivých účastníků správního řízení. Př́spěvek neposkytuje komplexní pojednání o problematice, resp. procesu dokazování, ale je zaměřen na fázi pořizování a provádění důkazů. $V$ úvodní části je věnována pozornost obecným východiskům a podstatě jednotlivých povinností správních orgánů v průběhu dokazování. Dále jsou zkoumány vybrané povinnosti správních orgánů ve fázi dokazování, a souběžně též korespondující vybraná práva účastníků řízení, a to s využitím aktuální relevantní judikatury.

\section{Obecná východiska}

V obecnější rovině bychom problematiku ochrany práv účastníků v rámci činností v průběhu opatřování podkladů pro vydání rozhodnutí a procesu dokazování mohli označit jako jeden ze základních principơ zajišt’ující dobrou správu. Ochrana práv účastníků v průběhu správního řízení (a to ve všech jeho fázích) by měla být v první řadě vždy zajišt'ována ze strany správních orgánů, a to nejenom z pohledu možného zásahu ze strany rozhodujícího správního orgánu, ale i v případě, kdy k zásahům do práv dochází ze strany ostatních účastníků správního řízení či ze strany jiných dotčených subjektů.

Jak bylo naznačeno, k zásahům do práv účastníků může docházet nejenom samotným porušením pravidel správního rrízení správními orgány (konkrétně oprávněnými úředními osobami), ale i zneužíváním práv jiným účastníkem daného řízení. Jak uvedl již anglický filozof John Stuart Mill „Svoboda jednoho konč tam, kde začiná svoboda drubého.“ Což lze vztáhnout i na současnost a samozřejmě lze tento známý citát použít i pro omezení zneužívání práv jedním účastníkem správního řízení na úkor druhého účastníka. Z tohoto důvodu existují pro uplatňování práv jednotlivými účastníky i určitá omezení. Limity uplatňování subjektivních práv účastníků jsou založeny zákonem (ve formě úpravy omezení, zákazů či způsobů uplatňování jejich práv). Kromě toho jsou bud’ výslovně upraveny, nebo alespoň uznávány i další obsahové, materiální korektivy práv a svobod, za které se obecně považuje veřejný pořádek, veřejná bezpečnost, dobré mravy, aj. Jak 
uvádí P. Svoboda, jedná se o ústavně chráněné hodnoty, v jejichž prospěch ústavní pořádek ČR výslovně nebo mlčky dovoluje omezovat základní práva. ${ }^{2}$

Konkrétní správní činnosti nemůže vykonávat správní orgán samostatně, ale tyto činnosti jsou vykonávány konkrétními osobami - úředníky, kteří jsou zaměstnanci veřejného sektoru. V tomto př́padě hovoříme o osobní, resp. osobnostním základu veřejné správy. Stejně tak povinnosti správních orgánů jsou konkrétně aplikovány vždy konkrétními lidmi. Jak uvádí správní řád v ustanovení \15 odst. 2, každé řízení vede tzv. oprávněná úřední osoba, která vykonává jednotlivé úkony. Z toho jednoznačně vyplývá, že při činnosti správních orgánů hraje důležitou roli i lidský faktor, nejenom konkrétní nastavení povinností či práv zákonem. Zákon nastavuje taktéž i ochranu práv účastníků v př́ípadě podjatosti konkrétního úředníka rozhodujícího ve věci.

\subsection{Vývoj úpravy dokazování a podkladů pro vydání rozhodnutí}

Samotný proces dokazování je možné považovat za jednu z nejstěžejnějších fází správního řízení. Legální definice pojmu dokazování v zákoně není obsažena, ale procesní kodex (správní rád) nastavuje určitá pravidla pro dokazování. Obecně lze pod pojmem dokazování rozumět proces získávání poznatků podstatných k posouzení projednávané věci. Jedná se o proces zjišt'ování pravdy v projednávané věci. Je nutné si uvědomit, že výsledkem dokazování není a ani nemůže být zjištění absolutní pravdivosti (či nepravdivosti) daných skutečností. Povinnost správního orgánu zjišt’ovat stav věci, o němž nejsou důvodné pochybnosti (srov. ustanovení \ 3 správního rádu), je promítnutím zásady materiální pravdy, tedy zásady vztahující se k určení rozsahu (a způsobu), v jakém (a jakým) správní orgán zjišt'uje skutečnosti, které jsou nutné pro provedení úkonu v určité věci, nejčastěji pro vydání rozhodnutî̉. Lze tedy hovořit o způsobu poznání skutečnosti, nebo-li zjišt’ování pravdy. Jak uvádí P. Svoboda, jedná se o postup orgánů př̀ zjišt’ování a hodnocení informací o skutečném stavu věci. Při tomto procesu orgán veřejné správy získává informace (poznatky) o skutečnostech významných pro rozhodování nebo jeho výkon z určitých pramenů či zdrojů informací. ${ }^{5} \mathrm{~V}$ teoretické rovině vymezuje dokazování např. V. Knapp, který člení teorie dokazování na logickou a procesně právní, kdy teorie logická je základem procesně právní teorie dokazování. ${ }^{6}$

2 SVOBODA, P. Ústavni základy správního rízeni v České republice. Právo na spravedlivý proces a Ceské správni rízení. Praha: Linde Praha, a. s., 2007, s. 56.

3 VEDRAL, J. Správní rád komentár. 2. vyd. Praha: Bova polygon, 2012, s. 111.

4 KLIKOVÁ, Alena, Petr HAVLAN, Marek CHADIMA, Jana JURNÍKOVÁ, Stanislav KADEČKA, Petr PRŮCHA, Stanislav SEDLÁČEK, Soňa SKULOVÁ a Jiří VENCLÍČEK. Správní rád. 2. vyd. Praha: Wolters Kluwer ČR, a. s., 2016, 652 s., s. 199. Meritum. ISBN 978-80-7478-943-4.

5 SVOBODA, P. Ústavní základy sprámího rízenív České republice. Právo na spravedlivý proces a Ceské správní rízení. Praha: Linde Praha, a. s., 2007, s. 341.

6 Viz KNAPP, V. Teorie práva. 1. vyd. Praha: C. H. BECK, 1995, s. 175. 
Správní rád jako základní kodex správního procesu všeobecně vymezuje pravidla procesu dokazování a pořizování podkladů pro vydání rozhodnutí a dále jednotlivých typů podkladů pro vydání rozhodnutí. Zakotvení konkrétních pravidel pro správní proces, včetně pravidel pro dokazování poprvé pro tehdejší Československo obsahuje první kodex správního řízení (vládní nařízení č. 8/1928 Sb., o řízení ve věcech náležejících do působnosti politických úřadů (správní ŕízení, který upravoval otázky dokazování jako tzv. důkazní řízení v \48-65. Tato ustanovení obsahovala jak obecná pravidla, tj. pořizování důkazů, charakteristika důkazů a práva a povinnosti účastníků ve vztahu k dokazování. Dále upravovala problematiku vybraných typů důkazů (listinou, svědeckou výpovědí, znalci, ohledání, osvědčenî).

Další vládní nařízení č. 20/1955 Sb., o rrízení ve věcech správních (správní řád), kterým bylo výše uvedené vládní nařízení nahrazeno, upravovalo problematiku dokazování pouze stručně, a to v $\int 20$. I v tomto vládním nařízení byla stručně zmíněna vybraná práva účastníků v rámci dokazování?

V roce 1960 bylo vydáno další vládní nařízení č. 91/1960 Sb., o správním řízení, které dokazování neupravovalo vůbec, pouze v ustanovení \8-9 je zakotvena problematika podkladů pro vydání rozhodnutí.

Správní řád č. 71/1967 Sb., který předcházel současnému správnímu řádu, opět problematiku dokazování obsahoval, a to v ustanovení \32-40. Upravuje jak jednotlivé typy vybraných důkazů, tak proces dokazování a práva účastníků v rámci dokazování.

V současné době je kodexem správního procesu zákon č. 500/2004 Sb., správní řád, ve znění pozdějších předpisů, který proces dokazování a podkladů pro vydání rozhodnutí upravuje v \50-57. Správní rád zakotvuje podklady pro vydání rozhodnutí v ustanovení \50 a dokazování v ustanovení \51-57. Jednotlivá ustanovení pak obsahujî nejenom úpravu konkrétního institutu, ale i souvisejících práv či povinností účastníků správního řízení.

Pro zjištění skutečného stavu věci slouží nejenom důkazy, ale i podklady pro vydání rozhodnutí. Rozdíl mezi podkladem pro vydání rozhodnutí a důkazem můžeme vymezit např. jazykovým výkladem daného zákonného ustanovení. Dle správního řádu jsou podklady pro vydání rozhodnutí vyjmenovány prŕkladmo, a to takto: „Podklady pro vydáni rozhodnuti mohou být zejména návrby účastnikei, dikeasy, skutečnosti známé správnimu orgánu z úredni činnosti, podklady od jiných správnich orgámu nebo orgánü verejné moci, jakož i skutečnosti obecně ₹námé. "Z jazykového výkladu tak lze usuzovat, že podklady pro vydání rozhodnutî zahrnují širší škálu než důkazy. Mezi důkazy nejsou např. zařazeny i skutečnosti známé správnímu orgánu z jeho úřední činnosti, či skutečnosti obecně známé, které není třeba

7 \20 odst. 2 věta první „Účastníci řízení mají navrhnout důkazní prostředky, které mají dokázat pravdivost jejich tvrzení.“ Správní orgán je však povinen provést všechny důkazy, které mohou přispět k úplnému objasnění věci, i když je nenavrhl žádný účastník. 
dokazovat. Jak uvádí rozhodnutí Nejvyššího správního soudu č. j. 1 As 33/2011-58 ze dne 12. 4. 2011 ,skutečnosti obecně známé (tzv. notoriety) obdobně jako skutečnosti známé správnímu orgánu z úřední činnosti (\$ 50 odst. 1 správního řádu) jsou objektivizované, do značné míry nesporné skutečnosti, které se v soudním či správním řízní zásadně nedokazují. “8 Dủkaz oproti podkladům pro vydání rozhodnutí lze tedy označit za pojem užší. Lze také uvést, že důkazy jsou jedním z podkladů pro vydání správního rozhodnutí. K provedení dokazování pak je možné užít všech důkazních prostředků, které jsou vhodné ke zjištění stavu věci a které nejsou získány nebo provedeny v rozporu s právními předpisy (zásada legality). Z toho vyplývá, že pro to, aby se určitá forma mohla považovat za důkaz, musí být splněny dvě podmínky. První je, že jsou vhodné ke zjištění stavu věci a druhou podmínkou je, že je prostředek získán v souladu se zákonem. ${ }^{9}$

Proces dokazování je možné z pohledu práv jednotlivých účastníků rozdělit na fázi před zahájením dokazování, tj. při pořizování důkazů a jiných podkladů pro vydání rozhodnutí a dále na fázi samotného dokazování. Dále lze také hovořit o skupině práv účastníků, které se uplatňují v celém procesu správního řízení. S některými právy účastníka pak zároveň koresponduje povinnost správního orgánu ve vztahu k zajištění řádného uplatnění procesních práv účastníků.

\section{Právo na spravedlivý proces ve správním řízení}

Zakotvení povinností správních orgánů by mělo ve vztahu k účastníkům řízení zajistit ochranu jejich práv v řízení. Základ úpravy povinností správních orgánů představuje ústavní princip legality. Jak je zakotveno v článku 2 odst. 2 Listiny základních práv a svobod „státni moc lze uplatňovat jen v pröpadech a v mezich stanovených zákonem, a to zpuisobem, k.terý zákon stanoví." Povinnosti správních orgánů by měly být stanovovány vždy zákonem.

Dle článku 36 Listiny základních práv a svobod má každý právo na to, aby jeho věc byla projednána nezávislým a nestranným soudem či jiným orgánem. Článek 38 odst. 2 Listiny základních práva a svobod taktéž zakotvuje právo účastníka na řádný proces. „Každý má právo, aby jeho věc byla projednána verejnè, bez. zbytečných pritabũ a v jeho prìtomnosti a aby se mobl vyjádrit ke v̌sem provádèným dìkazuim. “Jedná se o obecně nastavené právo osob na přiměřenou délku řízení, at’ už správního, či soudního řízení. Otázkou přiměřenosti délky řízení se zabývalo již mnoho autorů, soudů, ${ }^{10}$ včetně soudu ústavního. Toto obecné právo osob je ve správním řádu vyjádřeno mimo jiné i v obsahu základních zásad činnosti správních orgánů, a to $\mathrm{v}$ zásadě rychlosti (\$ 6 správního rádu). V př́padě porušení tohoto pravidla je možné uplatnit ochranu před nečinností dle správního řádu ( 80

8 VEDRAL, J. Správni rád komentár. 2. vyd. Praha: Bova polygon, 2012, s. 515.

9 VAČOK, J. Vybrané inštitúty ochrany zákonnosti v prvostupnovovom správnom konaní. 1. vyd. Bratislava: Univerzita Komenského v Bratislave, Právnická fakulta, 2014, s. 94.

10 Např. nález Ústavního soudu II. ÚS 71/99, III. ÚS 696/02. 
správního řádu), popř. stížnost dle $\int 175$ správního řádu na nesprávný úřední postup, popř. existuje i možnost ochrany soudní, a to žaloba dle $\int 79$ a násl. soudního řádu správního. Dle názoru autorky je ochrana před nečinností v současné době nastavena natolik podrobně a je dostatečně př́istupná pro každého, že není nutné ji doplňovat či rozšiřovat.

Výše popsané právo na spravedlivý proces vyplývá z čl. 6 odst. 1 Evropské úmluvy o ochraně lidských práv a svobod. Úmluva stanoví, že každý má právo, aby jeho záležitost byla projednána veřejně, spravedlivě a v přiměřené lhůtě před nezávislými soudy. Obecně lze vycházet z názoru V. Sládečka ${ }^{11}$, podle nějž lze některé požadavky čl. 6 odst. 1 Úmluvy ve správním řízení aplikovat přiměřeně. Dle judikatury Evropského soudu pro lidská práva se úmluva vztahuje nejenom na možnost projednání před nezávislými soudy, ale i na projednání před orgány veřejné správy, tj. i na správní řízení.

Každý má právo, aby jeho věc byla řádně projednána i v rámci správního řízení před správními orgány, a to v přměřené době. Postup správních orgánů je do jisté míry podobný soudnímu řízení. Správní řízení však vedou správní orgány a nikoliv nezávislé soudy. Ve srovnání se soudním řízením vykazuje správní řízení nižší míru formalizace, i když úpravou obsaženou ve správním řádu z roku 2004, se úroveň formalizace správního procesu nepochybně zvýšila oproti úpravě předchozí. Dalším odlišným znakem je pak zaměření správního řízení na plnění úkolů veřejné správy, s čímž je spojen také specifický vztah k naplňování veřejného zájmu (srov. \2 odst. 4 s.řx.). ${ }^{12}$

Jak uvádí V. Sládeček ${ }^{13}$, v rámci správního řízení však není naplněn požadavek na veřejné projednání, protože správní řízení je (až na výjimky ${ }^{14}$ ) neveřejné. Požadavku na veřejné projednání věci ve správním řízení (srov. čl. 38 odst. 2 Listiny) ve správním řádu koresponduje právo tzv. neopomenutelného účastníka řízení, resp. účastníka se silnějším postavením (účastník podle $\int 27$ odst. 1 správního řádu) prosadit, pokud tomu nebude bránit zákonná překážka, svým návrhem veřejně konané ústní jednání (viz \49 odst. 3

11 SLÁDEČEK, Vladimír. Obecné správní právo. 3., aktualiz. a upr. vyd. Praha: Wolters Kluwer Česká republika, 2013, s. 440.

12 KLIKOVÁ, Alena, Petr HAVLAN, Marek CHADIMA, Jana JURNÍKOVÁ, Stanislav KADEČKA, Petr PRU゚CHA, Stanislav SEDLÁČEK, Soňa SKULOVÁ a Jiří VENCLÍČEK. Správní rád. 2. vyd. Praha: Wolters Kluwer ČR, a. s., 2016, 652 s., s. 82. Meritum. ISBN 978-80-7478-943-4.

13 SLÁDEČEK, Vladimír. Obecné správni právo. 3., aktualiz. a upr. vyd. Praha: Wolters Kluwer Česká republika, 2013, s. 441.

14 Za takovouto výjimku by bylo možné považovat např. ustanovení $\int 87$ odst. 2 věta první a druhá stavebního zákona (zákon č. 183/2006 Sb., ve znění pozdějších předpisů), které stanoví jak možnost stavebního úřadu věc projednat veřejně, tak i jeho povinnost věc řešit veřejně: „V prǔpadech zámérü, pro které bylo vydáno stanovisko ke posouzeni vlivi provedeni zámèru na životni prostředí, mũže stavebni úrad nařdit k projednáni žádosti verejné ústni jednání. V prípadech zámèri umistovaných v území, ve keterém nebyl vydán územní plán, nař́di stavební úrad veřejné ústni jednáni vǒ̀dy.". 
správního řádu). ${ }^{15}$ Nicméně i přes určité výjimky je správní řízení obecně neveřejné. Dle názoru autorky ona neveřejnost pak musí být nahrazena jinými prostředky, které by zajistili právo na přístup $\mathrm{k}$ informacím o správním řízení.

Správní orgán by měl v rámci správního řízení zajistit účastníků alespoň minimální úroveň jejich procesních práv. Tato povinnost správního orgánu a právo účastníka je konkretizováno stanovením určitých povinností správních orgánů, které vymezují, jak musí správní orgán postupovat, aby zabezpečil práva dotčených účastníků. Stejně tak zákon vymezuje některá konkrétní práva účastníků v rámci správního řízení.

S právem na spravedlivý proces je úzce spjato právo účastníka na zjištění skutkového stavu věci. Jak již bylo uvedeno výše, postup orgánů veřejné správy při zjišt’ování skutkového stavu věci se nazývá dokazování. Proces dokazování pak můžeme označit v jistém ohledu jako středobod celého správního řízení. ${ }^{16}$ Řádné a kvalitní dokazování je podstatné pro spravedlivým, řádný proces, nebot’ správně zjištěný skutkový stav věci, je východiskem pro rozhodnutí správního orgánu.

\section{Povinnosti správních orgánů v rámci dokazování}

Správní orgány jsou povinny ve správním řízení postupovat tak, aby byly dodrženy veškeré základní zásady činnosti správních orgánů, základní zásady správního řízení, principy dobré správy a samozřejmě zákon. Jednou ze základních zásad činností správních orgánů je zásada legality (zákonnosti), která je základní podmínkou veřejné správy. Lze ji označit za garanci ústavní zásady legality ve sféře veřejné správy, zakotvené v Ústavě ČR a Listině základních práv a svobod. Konkrétně ji nalezneme v ustanovení článku 2 odst. 3 Ústavy a v článku 2 odst. 2 Listiny základních práv a svobod: „Státní moc lze uplatnovat jen v prípadech a v mezich stanovených zákonem, a to zpiosobem, který zákon stanovi." Taktéž lze její základ nalézt v článku 4 odst. 1 Listiny základních práv a svobod: „Povinnosti mohou být ukládány toliko na základě zákona a v jeho mezích a jen pri zachování základních práv a svobod." Jak uvádí S. Skulová, zásada legality rovněž představuje jednu ze záruk zákonnosti v oblasti veřejné správy. Mimo sféru jejîho uplatnění by neměl zůstat žádný z postupů, kterými subjekty vykonávající veřejnou správu zasahují do právních poměrů adresátů veřejné správy nebo na ně jinak působí. Rovněž z tohoto důvodů je zásada legality, a zároveň s ní další základní zásady činnosti správních orgánů, nastavena jako zásada univerzální, ovládající výkon veřejné správy. ${ }^{17}$

15 KLIKOVÁ, Alena, Petr HAVLAN, Marek CHADIMA, Jana JURNÍKOVÁ, Stanislav KADEČKA, Petr PRŮCHA, Stanislav SEDLÁČEK, Soňa SKULOVÁ a Jiří VENCLÍČEK. Správní rád. 2. vyd. Praha: Wolters Kluwer ČR, a. s., 2016, 652 s., s. 89. Meritum. ISBN 978-80-7478-943-4.

16 SVOBODA, P. Ústavní zákelady správního řįenív České republice. Právo na spravedlivý proces a Ceské správní rízení. Praha: Linde Praha, a. s., 2007, s. 304.

17 Ibidem, s. 37. 
Povinnost dodržovat zákon je jednou z povinností správního orgánu, která se prolíná celým procesem (at' už procesem správního řízení nebo i jinou činností správního orgánu). Řada povinností správních orgánů je upravena pro fázi opatřování důkazů či jiných podkladů pro vydání rozhodnutí. Další část je vymezena v rámci samotného procesu provádění důkazů.

\subsection{Fáze opatřování důkazů}

Před samotným procesem provádění dokazování je správní orgán povinen opatřit jednotlivé podklady a důkazy, na základě kterých je schopen posoudit stav projednávané věci, o kterém nejsou důvodné pochybnosti. Jak bude uvedeno dále, za určitých podmínek, může na požádání účastníka správní orgán připustit, aby za něj podklady pro vydání rozhodnutí opatřil tento účastník. Povinnost opatřovat veškeré podklady a důkazy je jinak svěřena správnímu orgánu (s výjimkou řízení sporného - viz níže). Správní orgán je povinen veškeré podklady opatřovat v souladu se zákonem. Nezákonně opatřený důkaz, nelze ve správním řízení využít (viz \51 odst. 1 správního řádu). Na stranu druhou jak uvádí jeden z komentářo ke správnímu řádu ${ }^{18}$ sice nezákonně pořízený důkaz nelze použít jako důkazní prostředek, ale některé údaje v něm uvedené mohou být určitým signálem k získání poznatků relevantních pro dané řízení. Dle ustanovení \ 2 odst. 4 správního řádu je správní orgán taktéž povinen zjistit všechny okolnosti důležité pro ochranu veřejného zájmu.

V řízení z moci úřední se uplatňuje zásada vyšetřovací, kdy správní orgán je povinen i bez návrhu zjistit všechny rozhodné okolnosti svědčící ve prospěch i v neprospěch toho, komu má být uložena povinnost. Z judikatury vyplývá, že se správní orgán v těchto řízeních a s odkazem na zmíněnou zásadu vyšetřovací nemůže odkazovat a spoléhat pouze na důkazy navržené účastníky, ale musí sám provádět zjišt’ování a vyšetřování v projednávané věci. Jedním z důvodů je i to, že účastníci mohou navrhovat důkazy a uvádět argumenty ryze účelově. Jako př́klad můžeme uvést nap̌r. rozhodnutí Městského soudu v Praze ${ }^{19}$ ze dne 30. 10. 2014, č. j. 7 A 136/2011-50, které uvádí: „V posuzovaném prǐpadě roz̧hodl stavebni úrad o odstranèni stavby, aniž by sám skutkový stav na misté zkoumal, resp. zkoumal-li jej, nelze takový postup ze správního spisu nijak seznat. Pokud stavebni úrad vycházel

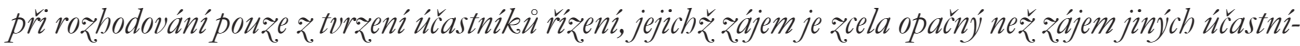
kư, aniž by prokazatelnè sám zjištoval skutkový stav (srov. @ 50 odst. 2 správního rádu, který ukládá správnimu orgánu povinnost opatrit podklady pro vydáni rozhodnuti), nelze takový postup správního orgánu posoudit jako souladný se zákonem. "Jedná se o jednu z povinností správního orgánu, jejíž dodržení je způsobilé zajistit ochranu práv jednoho účastníka před jiným účastníkem správního řízení majícím opačný zájem.

18 JEMELKA, L., K. PONDĚLÍČKOVÁ a D. BOHADLO. Spráuní rád. Komentár. 3. vyd. Praha: C. H. Beck, 2011, s. 209.

19 Rozhodnutí Městského soudu v Praze ze dne 30. 10. 2014, č. j. 7 A 136/2011-50. 
Jednotlivé pořízené důkazy musí splňovat nejenom požadavek na jejich zákonné pořízení, ale musí být dostatečně jasné, průkazné, musí z nich být jasný vztah k projednávané věci, musí být dostatečně relevantní a jednoznačné. Tato povinnost je výrazně zřejmá ve vztahu k řízením zahajovaným z moci úřední, nebot’ u těchto řízení většinou dochází k uložení povinnosti dotčeným účastníkům. Jak uvádí Nejvyšší správní soud v rozsudku ze dne 30. 12. 2010, č. j. 4 Ads 44/2010-132 „Zejména v sankínich spráunich rǐzeních zahajovaných ex offo je prí zjiš́t’ováni skutkovébo stavu kladen zuláśtni dirraz na naplnèni zásady materiálni pravdy dle $\int 3$ správního rádu, a zásady vy šetrovaci dle $\int 50$ odst. 3 tohoto zákona. Dikeazni prostredky, keteré nesplnuuji dostatečnou míru konkerétnosti, jednoznačnosti a prỉkaznosti, je nutné odmitnout jako nevyhovijicí. “20

V další části př́ispěvku je podrobněji pojednáno o možnosti účastníka správnímu orgánu navrhnout důkazy na podporu svých tvrzení, kdy tímto návrhem není správní orgán vázán.

\subsection{Fáze provádění důkazů}

Pro provádění důkazů platí řada obecných pravidel, které pro svou obsáhlost není možné zde konkrétněji zpracovat, a proto bude pozornost věnována pouze vybraným institutům, které mají vztah k níže zmíněným právům účastníků v procesu dokazování. I samotný proces dokazování musí být v souladu se zásadou legality, tj. nejenom pořízení důkazů musí být v souladu se zákonem, ale i provádění důkazů.

Aby účastníci měli možnost řádně hájit svá práva v průběhu dokazování, musí je správní orgán informovat o tom, že bude určitý dưkaz provádět, bude-li jej provádět mimo ústní jednání. Dle rozhodnutí Nejvyššího správního soudu ze dne 29. 5. 2014, č. j. 5 Azs 2/2013-26 „Rouněžv rízeni o žádosti o udèleni mezinárodni ochrany je správni orgán povinen podle $\int 51$ odst. 2 správního rádu z.r. 2004 véas uvédomit žadatele o provádèni duikazui mimo ústní jednání, a to mj. výslechem svédkea, a umožnit tak žadateli, aby byl výslechu prítomen."

Obdobné povinnosti správních orgánů jsou zakotveny i v rakouské právní úpravě obecného správního řízení (AVG - Allgemeines Verwaltungsverfahrensgesetz). V ustanovení \37 AVG uvádí, že účelem šetření pro vyřízení správní záležitosti je zjistit rozhodující stav věci a stranám poskytnout možnost $k$ uplatnění jejich práv a právních zájmů. Obdobně ustanovení \47 odst. 3 AVG uvádí, že stranám má být dána možnost vzít na vědomí výsledek důkazního rrízení a tomuto se vyjádřit. Účastníkům taktéž musí být dán správním orgánem prostor se aktivně zapojit do správního řízení.

Základním pravidlem pro posuzování a hodnocení podkladi̊ pro rozhodnutí a pro vlastní hodnocení důkazů je zásada volného hodnocení důkazů. Správní orgán je podle této zásady povinen brát $\mathrm{v}$ úvahu všechny relevantní skutečnosti a důkazy a provést s nimi potřebné logické operace, z nichž vzejde řešení (ve správním řízení rozhodnutí ve věci),

20 Rozhodnutí Nejvyššího správního soud ze dne 30. 12. 2010, č. j. 4 Ads 44/2010-132. 
jež bude vycházet ze skutkového stavu dostatečně zjištěného (návaznost na zásadu materiální pravdy). ${ }^{21}$ Zásada volného hodnocení důkazů znamená, že žádný z důkazů nemá v různou právní či faktickou sílu a je vždy na samotném správním orgánu jakou váhu dle své úvahy príisoudí tomu kterému důkazu. Volné hodnocení důkazů je však možné v př́padě důkazů, které nejsou ze zákona závazné. Správní rád počítá v ustanovení \50 odst. 4 s existencí závazných podkladů pro rozhodnutí, které správní orgán povinnè musí vzít v úvahu. Závaznost jednotlivých podkladů pro vydání rozhodnutí může vycházet např. obecně z charakteru daného podkladu, konkrétně se může jednat o závazné stanovisko dotčeného orgánu, které správní orgán rozhodující ve věci již nehodnotí, ale rozhoduje v souladu s ním (srov. ustanovení S 149 odst. 3 správního ráádu). Jak uvádí S. Skulová, znamená to, že volné hodnocení důkazů se uplatní pouze, avšak s plnou intenzitou, ve zbývajícím prostoru posuzování skutkové stránky věci. Pokud uvedené závazné podklady nejsou stanoveny, uplatní se volné hodnocení důkazů zcela. ${ }^{22} \mathrm{Na}$ zásadu volného hodnocení důkazů navazuje povinnost ráádného odůvodnění úvah správního orgánu při hodnocení důkazů.

\section{Práva účastníků v rámci dokazování}

$\mathrm{V}$ rámci formalizovaného postupu správního orgánu vưči adresátovi veřejné správy (správní řízenî) musí správní orgán adresátovi (účastníkovi) zajistit minimální úroveň procesních práv. Mezi nejzásadnější z nastíněných práv patří právo být slyšen. Toto právo má adresátovi zajistit, že nebude jen „objektem řízeni““, ale zejména subjektem řízení, tedy tou osobou, jejíž oprávněné zájmy a práva budou v řízení relevantně posuzovány. Právo být slyšen pak má jeden základní cíl, a to dát adresátu veřejné správy možnost aktivně se zapojit do řízení a vyžadovat od správního orgánu, aby to nejen respektoval, ale zejména na jeho projevy reagoval. ${ }^{23}$ Právo být slyšen se projevuje v dalších zákonem či obecnými principy vymezených právech účastníka. Jak bude uvedeno dále lze právo být slyšen považovat za jedno z nejpodstatnějších práv účastníka.

Níže se budeme věnovat konkrétně vymezeným právům účastníka v průběhu dokazování, které v sobě mimo jiné obsahují právo být slyšen. V rámci jednotlivých práv můžeme vysledovat téměř vždy právo účastníka se vyjadřovat a zasahovat do dokazování, tj. jeho právo být slyšen. Jak bylo zmíněno $\mathrm{v}$ předchozí kapitole, i práva účastníků v rámci dokazování lze rozdělit dle fáze dokazování, tj. na fázi před procesem dokazování, dále

21 KLIKOVÁ, Alena, Petr HAVLAN, Marek CHADIMA, Jana JURNíKOVÁ, Stanislav KADEČKA, Petr PRŮCHA, Stanislav SEDLÁČEK, Soňa SKULOVÁ a Jiří VENCLÍČEK. Správní rád. 2. vyd. Praha: Wolters Kluwer ČR, a. s., 2016. 652 s., s. 97. Meritum. ISBN 978-80-7478-943-4.

22 In: KLIKOVÁ, Alena, Petr HAVLAN, Marek CHADIMA, Jana JURNÍKOVÁ, Stanislav KADEČKA, Petr PRŮCHA, Stanislav SEDLÁČEK, Soňa SKULOVÁ a Jiří VENCLÍČEK. Správní rád. 2. vyd. Praha: Wolters Kluwer ČR, a. s., 2016. 652 s., s. 97. Meritum. ISBN 978-80-7478-943-4.

23 BRAŽINA, R. Právo být slyšen ve správním ríz̨ení. Seminární práce. Brno: PrF MU, 2016. 
na samotnou fázi provádění dokazování a práva, která svědčí účastníkům po celou dobu správního řízení. Níže se budeme podrobněji věnovat jednotlivým právưm účastníků v rámci těchto fází dokazování.

\subsection{Fáze před prováděním dokazování}

Povinnost pořizovat podklady pro vydání rozhodnutí a jednotlivé důkazy je zákonem určena správnímu orgánu, i když správní řád umožňuje určité výjimky. Např̀. v rámci sporného řízení je dle ustanovení \ 141 odst. 4 správního řádu povinnost obstarat důkazy na podporu svých tvrzení dána účastníkům konkrétního řízení. Správní orgán ve sporném řízení věc posuzuje v návaznosti na důkazy obstarané a předložené účastníky. Sporné rrízení je však výjimkou z obecného pravidla, kdo je povinen obstarávat a pořizovat důkazy. S obecně zakotvenou povinností správního orgánu pořídit podklady pro vydání rozhodnutí jsou spojena práva účastníků v rámci tohoto procesu pořizování důkazů a podkladů pro rozhodnutí.

Základní právo účastníka je zakotveno v ustanovení \36 odst. 1 správního řádu, dle kterého má účastník právo navrhovat důkazy a činit jiné návrhy, a to po celou dobu řízení, až do vydání rozhodnutí. Lhůta pro činění návrhů je správním řádem omezena až okamžikem vydání správního rozhodnutí, což může občas vést k účelovým jednáním jednotlivých účastníků, kteří budou postupně podávat návrhy na další důkazy a tím zdržovat správní rúizení. Správní orgán sice nemusí k návrhům přihlížet (viz níže), ale vždy se s návrhem musí vypořádat. Je tedy vhodné, pokud je lhưta pro podávání návrhů na dokazování omezena. Lhůta může být omezena bud’to správním orgánem nebo př́mo zvláštním zákonem. Typický př́iklad zákonného omezení lhưty pro podávání návrhů a námitek je stavební zákon (zákon č. 183/2006 Sb., ve znění pozdějších předpisů), který určuje termín, do kterého je možné podávat námitky k předloženému záměru, tj. stanovuje koncentraci ř́zení. Koncentrace při podávání námitek je stavebním zákonem omezena nejenom ve vztahu k času, ale i ve vztahu k typu řízení, nebot' ustanovení $\int 114$ odst. 2 stavebního zákona určuje i povinnost námitky, které mohly být uplatněny v územním řízení, uplatnit výhradně v tomto typu řízení, s tím, že ve stavebním řízení k nim již nebude přihlíženo. Koncentrační zásada ve vztahu k územnímu řízení byla již několikrát potvrzena soudními rozhodnutími, např. rozsudek NSS sp. zn. 1 As 107/2012 nebo rozsudek NSS sp. zn. 8 As 54/201124. Nejvyšší správní soud dále např. v rozsudku ze dne 28. 7. 2010, č. j. 5 As 77/2009-107, vyslovil, že „v územním rízení stavebni úrad posuzuje, zda je dokumentace zámèru v souladu súzemnè plánovaci dokumentaci (územním plánem) a vydáním územního rozhodnuti tento soulad konstatuje. Shledá-li stavebni úrad rozpor s územně plánovaci dokumentací, žádost o vydáni roz̧hodnuti o umistèni stavby zamitne. Pokud se uičastník rízeni

24 Jde o vyjádření principu tzv. koncentrace, který vyjadřuje požadavek, aby námitky, které se věcně vztahují $\mathrm{k}$ určitému typu ř́zení, byly uplatňovány právě v onom řízení a nebylo možné jimi argumentovat $\mathrm{v}$ ř́izení jiném. 
domnivá, že plánovaná stavba v souladu s územním plánem není, je oprávnèn brojit proti územnimu roz̧odnuti prostrednictvím opravných prostredkư ve správnim rízeni, př́padně následně v rǐzeni prèd

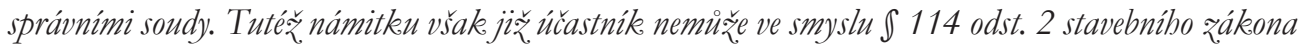

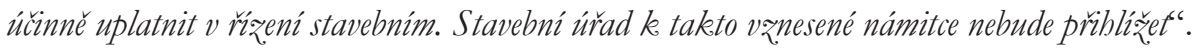

Koncentrace řízení je dle názoru autorky efektivním nástrojem jak zabránit spekulativnímu jednání ze strany těch účastníků, kteří mají protichůdný zájem v rámci správního řízení. Je však otázkou, zda se vždy musí jednat o zákonnou koncentraci anebo zda postačí koncentrace řízení určená správním orgánem v rámci jeho činnosti. V této souvislosti je vhodné zmínit obecné pravidlo o lhưtách. Lhůty stanovené zákonem nelze prodlužovat, zatímco dle ustanovení \39 odst. 2 správního řádu lhưtu určenou správním orgánem lze prodloužit. Pokud se tedy bude jednat o koncentraci určenou správním orgánem, bude opět záležet na lidském faktoru a na rozhodnutí oprávněné úřední osoby, zda lhůtu neprodlouží, čímž opět dochází k určité nejistotě účastníků řízení.

S výše uvedeným právem navrhovat důkazy je spojena i povinnost účastníka, a to v ustanovení \52 správního řádu: „účastník je povinen označit důkazy na podporu svých tvrzení". I když s nesplněním této povinnosti není spojena žádná sankce. Pokud však za sankci nepovažujeme nap̌r. rozhodnutí v neprospěch účastníka, který řádně neoznačil důkazy na podporu svých tvrzení. Jak bylo uvedeno výše, nesplnění této povinnosti může být účastníkovi na újmu např. v ř́zení sporném, ve kterém je povinnost zajistit důkazy přenesena na účastníka. $V$ jiných typech řízení má správní orgán povinnost zjistit skutečnosti, o kterých nejsou důvodné pochybnosti. Za určitou sankci za nesplnění povinnosti účastníkem dle $\int 52$ správního řádu, bychom mohli považovat ustanovení \ 71 odst. 5 správního řádu, které stanoví nemožnost účastníka se dovolávat nedodržení lhưt, pokud to způsobil např. sám nedodržením svých procesních povinností. ${ }^{25}$ Je nutné upozornit na fakt, že samotné ustanovení \ 52 správního řádu neurčuje povinnost správního orgánu, aby účastníkem navržené důkazy provedl, nebot’ není vázán návrhy účastníků. Nicméně když k těmto návrhům správní orgán nepřihlédne, musí se s nimi vždy velmi pečlivě vypořádat v odůvodnění a vysvětlit proč návrhu účastníka nevyhověl. K této otázce se již vyjadřoval i Ústavní soud a jak uvádí dr. Vedral ve svém komentárí, sice se nález týkal soudního řízení, ale závěry v něm uvedené lze vztáhnout i na správní řízení. Ústavní soud v nálezu ÚS I. 729/2000 ze dne 8. 12. 2005 uvedl, že pokud soud (správní orgán) nevyhoví návrhu účastníka, musí v rozhodnutí vyložit, z jakých důvodů navržené důkazy neprovedl, zpravidla ve vztahu $\mathrm{k}$ hmotněprávním předpisům, které aplikuje a $\mathrm{k}$ právním závěrům, $\mathrm{k}$ nimž na skutkovém základě dospěl. Nebo rozhodnutî III. US 58/2000. Stejně tak tuto povinnost správním orgánům pak potvrdilo rozhodnutí

25 KLIKOVÁ, Alena. Procesní práva účastníků v rámci dokazování ve správním ř́zení. In: ČIČKÁNOVÁ, Daniela, Ivana HAPČOVÁ a Vladislav MIČÁTEK. Sborník príspevkov mezinárodnej vedeckej konferencie Bratislavské práunické fórum 2015. 1. vyd. Bratislava: Univerzita Komenského Bratislava Právnická fakulta, 2015, s. 331-334. ISBN 978-80-7160-411-2. 
NSS ze dne 13. 4. 2012, sp. zn. 2 As 47/2011. Také rozhodnutí Nejvyššího správního soudu ze dne 13. 11. 2009, č. j. 5 As 29/2009-48 „Neni na libovili správního orgánu, jakým zpiosobem s návrby účastnikè na provedeni dỉkazui naloží, nebot’ správni orgán sice není ve smyslu

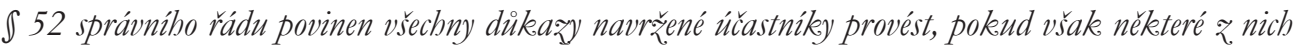
neprovede, musi v odivvodnèni roz̧bodnuti uvést, proč se tak stalo. Správni orgán je oprávnèn, ale i povinen odpovèdně vážit, k.teré dỉkazy je treba provést, zda je potrebné stav dokazováni doplnit a posuzovat dìvodnost návrbu stran na doplnèni dokazováni. Zásada volnébo bodnoceni dukazu nezৃnamená, že by bylo roz̧hodujicimu orgánu dáno na výbèr, které z.provedených duikazu vyhodnoti a které nikoli a o keteré opré skutkové závéry a které opomene. "V návaznosti na povinnost rádného odůvodňování je nutné zmínit, že by správní orgán měl taktéž odůvodnit, proč určité navržené důkazy provedl a samozřejmě jak je provedl. Jedná se o jeden z projevư zásady volného hodnocení důkazů, kdy správní orgán má možnost na základě zhodnocení neprovést účastníkem navržené důkazy, ale není to na jeho libovůli.

Možnost navrhovat důkazy na podporu svých tvrzení existuje i v rakouské úpravě obecného správního řízení v obecném správním řádu. Jak uvádí M. Horáková a V. Tomoszková důkazním návrhům, které jsou zjevně neopodstatněné, správní úrad není povinen vyhovět. Taková situace může podle Soudního dvora správního nastat jen tehdy, když navrhovaný důkazní prostředek objektivně vzato není vưbec způsobilý o předmětu dokazování důkaz podat. Naopak opodstatněný je důkazní návrh tehdy, když označuje dưkazní téma i dưkazní prostředek a důkazní téma přitom může prrispět $\mathrm{k}$ objasnění relevantního skutkového stavu. ${ }^{26} \mathrm{~V}$ této souvislosti se nabízí otázka, zda by obdobná podrobnější úprava nepřinesla zvýšení právní jistoty účastníků ve správním řízení v České republice, nebot’ by existovalo objektivně nastavené pravidlo, kdy správní orgán nebude přihližet k návrhům důkazů jednotlivými účastníky. Z výše uvedených soudních rozhodnutí sice obdobné pravidlo jednoznačně vyplývá, nicméně i nadále bude vždy na určitém subjektivním posuzování konkrétní úřední osoby, zda navržený důkaz provede či nikoliv. Výše položenou otázku pak lze rozšíríit na to, zda tedy řádné odůvodnění, proč správní orgán důkaz neprovedl, postačí k tomu, aby byl navržený důkaz více méně bezdůvodně odmítnut? Domnívám se, že nikoliv. Dle mého názoru by odmítnutí provedení navrženého dưkazu mělo být výhradně z objektivních důvodů, nap̌r. těch, se kterými počítá rakouská právní úprava.

Pro zajímavost lze zmínit i právní úpravu Polskou, která stanoví, že navržený důkaz, může správní orgán odmítnout formou usnesení, proti kterému je možné se odvolat. ${ }^{27}$ Správní orgán také nesmí přistupovat k navrženým podkladům a důkazům jednotlivými účastníky odlišně. Nelze prioritně provést některý z navržených důkazů a $\mathrm{k}$ jiným se nevyjádřit. Taktéž pokud tak nestanoví zákon, nelze některé podklady považovat

26 HORÁKOVÁ, M., V. TOMOSZKOVÁ a kol. Správin ř̌zení v zemich EU. Rakousko, Polsko, Slovensko a Mad'arsko. Praha: Linde Praha, a. s., 2011, s. 93.

27 Ibidem, s. 164. 
za závazné pouze z libovưle správního orgánu. Viz např̀. rozsudek Krajského soudu v Praze ze dne 27. 11. 2014, č. j. 47 A 15/2012-152 „...Správe povodí neni totéž co dotčený orgán (srov. \149 odst. 1 správního rádu), jeho stanoviska - byt tréba pro určitý typ rozhodnutí zákonem obligatornè vy žadovaná jako podklad - nemaji pro rozhodováni vodoprávnich úradư závazny charakter. Proto v prǒpadè, kedy vodoprávni úrad provádi dokazováni dvèma odlišnými znaleckými posudky, tak na vyjádřeni správce povodí [v dané véci osoby zúčastnèné] poskytnutému v souvislosti s hodnocenim tèchto posudkim je tréba nabližet nikoliv jako na revizni posudek, ale jako na vyjádreni

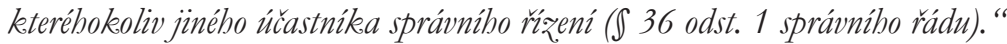

Odlišná je situace, kdy správní orgán jako podklad pro vydání rozhodnutí obdrží závazné stanovisko dotčeného orgánu, které je ze své podstaty závazné pro další rozhodování správního orgánu. Dle ustanovení \149 správního řádu je závazné stanovisko závazným podkladem pro vydání rozhodnutí ve věci a proto správní orgán musí postupovat výhradně v souladu se závěry v tomto závazném stanovisku.

Dalším právem účastníka spojeným s pořizováním dưkazů je jeho právo požádat správní orgán, aby na místo něj pořídil podklady pro vydání rozhodnutí on sám ( 50 odst. 2 správního řádu). I s tímto právem je spojena povinnost účastníka dle stejného ustanovení, a to povinnost účastníka poskytovat veškerou potřebnou součinnost správnímu orgánu při pořizování podkladů pro rozhodnutí. Nesplnění této povinnosti účastníka je opět problematické sankcionovat. Opět bychom zde mohli zmínit pouze sporné řízení, ve kterém je možné uvést jako určitou sankce neunesení důkazního břemene. Dle názoru soudů nezbavuje nečinnost účastníka správní orgány povinnosti zjistit skutečný stav věci, např. rozhodnutí Nejvyššího správního soudu ze dne 26. 7. 2005, č. j. 4 As 51/2004-82 „...podle \34 odst. 3 správního rádu je účastnike povinen navrbovat na podporu svých turzeni dukeazy, keteré jsou mu známy, avšak nesplnèni této povinnosti nezbavuje správni orgán povinnosti zjistit skutečnosti potrébné pro rozhodnutí. Podle $\int 73$ odst. 2 zákona o prestupcich nesmí být obvinèný z. prestupku k výpovédi ani k doznáni donucován. Přes výšse uvedená ustanoveni vǐak je správni orgán povinen spoleblivě zjïstit skutkový stav véci. Znamená to tedy, že i kedyž stéžovatelka v prüběbu správního rízeni zuistala naprosto nečinná, nezbavovala tato skutečnost správni orgány povinnosti żïstit skutečný stav věci, a prédevšm prokázat, že stě̃̌ovatelka svým jednáním naplnila zákonné znaky skutkové podstaty prérinu uvedeného v $\int 30$ odst. 1 písm. i) zákona č. 200/1990 Sb.“"

\subsection{Fáze provádění dokazování}

Účastník může aktivně vystupovat nejenom v procesu pořizování důkazů, ale taktéž v procesu samotného provádění důkazů.

Účastník má právo být informován o provádění důkazů mimo ústní jednání, s čímž tedy koresponduje povinnost správního orgánu účastníka o této skutečnosti informovat (srov. ustanovení $\int 51$ odst. 2 správního řádu). V případě, že správní orgán včas neinformuje účastníka o provádění dokazování, dojde tím k závažnému porušení práva tohoto účastníka, které nelze zhojit jiným postupem, např. tím, že je účastníkovi dána možnost 
se vyjádřit k podkladům před vydáním rozhodnutí. Každý účastník by měl mít možnost se zúčastnit procesu dokazování a taktéž do něj určitým zpo̊sobem aktivně zasahovat. Vždy by se však mělo dít pouze v souladu se zákonem a s obecnými principy správního procesu.

Zákon sice výslovně nehovoří o právu účastníka být přítomen dokazování, ale z některých ustanovení týkajících se konkrétního provádění důkazů a z obecného práva účastníka se účastnit projednávání jeho věci, toto právo vyplývá. Např. \53 odst. 6 správního řádu - provádění důkazu listinou za přítomnosti účastníků. Toto ustanovení nehovoří o nutnosti účasti účastníků v rámci provádění důkazu listinou, ala na stranu druhou z jazykového výkladu daného ustanovení je zřejmé, že zde tato možnost existuje. Domnívám se, že se jedná o významné právo účastníka, které mu nemưže být upíráno. Každý účastník má právo se v průběhu dokazování také aktivně do tohoto procesu zapojit, a to např̀. klást otázky svědkům. Toto právo zakotvoval starý správní ráa č. 71/1967 Sb. v ustanovení \ 33 odst. 1 ,právo klást svédkưm a znalcuim otázky pru ústnim jednáni a mistním obledáni". Toto právo v současném znění správního řádu sice není, ale dle mého názoru není důvod toto účastníkovi v rámci uplatňování jeho práv neumožnit, což potvrdilo např. rozhodnutí Krajského soudu v Hradci Králové ze dne 24. 4. 2013, 61 A 1/2013-44 „Provedl-li správni orgán prvního stupně dikaz výslechem svédka tak, že svoji aktivitu vyčerpal podáním poučení, pričemž následnè ukončil dokazováni s odkazem na to, že obvinèný neni schopen klást svédkovi dotazy, nelze toto provedeni dỉkazu považovat za rádné v souladu s $\int 52$ správního rádu z. roku 2004.“. ${ }^{28}$ V této souvislosti je vhodné zmínit právní úpravu zákona o odpovědnosti za přestupky a řízení o nich, zákon č. 250/2016 Sb., kde se v ustanovení \ 82 odst. 3 výslovně upravuje možnost účastníků klást otázky sobě navzájem, svědkům a znalcům. Právo klást otázky je v rámci řízení o přestupcích upraveno i pro zákonné zástupce a opatrovníky mladistvého obviněného, dále osoby přímo postižené spácháním přestupku, které daly souhlas se zahájením nebo pokračováním řízení, stejně tak i orgán sociálně-právní ochrany dětí.

O opaku lze hovořit v rakouské právní úpravě, která mezi právo být slyšen ve správním řízení nezahrnuje právo na prítomnost. Jak uvádí M. Horáková a V. Tomoszková z práva na slyšení nevyplývá subjektivní nárok na ústní slyšení. Účastník nemá právo být osobně př́tomen výslechu svědka a ani právo klást svědkům dotazy. ${ }^{29}$

28 Http://www.nssoud.cz/files/EVIDENCNI_LIST/2013/61A_1_2013_44_20130529082515_prevedeno.pdf

29 VwGH ze dne 25. 9. 1991, č. j. 91/02/0032. [online][cit. 2017-08-05]. Dostupné z: https://www.ris.bka. gv.at/Dokumente/Vwgh/JWT_1991020032_19910925X00/JWT_1991020032_19910925X00.pdf HORÁKOVÁ, M., V. TOMOSZ̄KOVÁ a kol. Sprámní rízení v zememích EU. Rakousko, Polsko, Slovensko a Madarsko. Praha: Linde Praha, a. s., 2011, s. 93. 


\subsection{Obecná práva účastníků}

V návaznosti na výše uvedené členění práv účastníků dle fází dokazování, mưžeme vymezit i třetí oblast práv účastníků, a to práva, která může účastník uplatňovat po celou dobu správního řízení, bez ohledu na fázi dokazování. Jedná se o práva vyjádřená v obecné rovině jako základní principy správního řízení, dále o práva účastníka vymezena $\mathrm{v}$ ustanovení \36 správního řádu a dále práva vyplývající z ústavních principů. Obecná práva účastníka lze uplatňovat nejenom v rámci dokazování, ale i v jiných fázích správního řízení.

Dalším požadavkem je projednání věci za př́itomnosti účastníka. Opět se jedná o pravidlo, které je zakotveno ve správním ráádu a to povinností správního orgánu informovat účastníka o provádění dokazování a možností účastníka se dokazování účastnit. Stejně tak i možnost vyjádřit se k prováděným důkazům je řešena správním řádem (viz výše).

Dle ustanovení \ 4 odst. 3 správního řádu má účastník právo být s dostatečným předstihem uvědoměn o úkonu, který správní orgán učiní, je-li to potřebné k hájení jejich práv a neohrozí-li to účel úkonu. O povinnosti předem účastníka informovat o dalších krocích již bylo pojednáno výše ve vztahu ke konkrétním právnům účastníka v průběhu dokazování, a proto se zde autorka o právu zmíní již pouze v obecné rovině. Rozhodnutî Nejvyššího správního soudu ze dne 30. 3. 2016, č. j. 10 As 5/2016-36 uvádí, že je povinností správního orgánu informovat účastníka např. o změně v jeho postupu v rámci doručování. ${ }^{30}$ Obecně lze dovodit, že správní orgán nemusí informovat účastníka o věcech, které jsou účastníkovi známy, ale musí jej informovat o změně praxe v řízení, či o věcech, které by mohly účastníkovi napomoci v uplatnění jeho práv, kdy umožnění uplatnění práv účastníka správním orgánem je zakotveno v ustanovení \ 4 odst. 4 správního řádu.

Za jedno z nejdůležitějších práv účastníka lze označit právo na řádné poučení o jeho právech, a to nejenom ve vztahu k dokazování, ale obecně k celému procesu správního řízení. K povinnosti poučovat účastníky se již mnohokrát vyjadřovaly i soudy. A to nejenom k povinnosti poučovat, ale i k určitému rozsahu samotného poučení. Nejvyšší správní soud např. v rozsudku ze dne 13. 10. 2010, č. j. 1 As 51/2010-214 uvedl „Pončovaci povinnost správního orgánu dle $\int 4$ odst. 2 správního rádu z roku 2004 nezabrnuje poskytováni komplexního návodu, co by účastnike mél nebo mobl v daném prípadě dèlat, aby dosábl záádaného úcinku, ale jen pomoc k tomu, aby mohl zákonem stanoveným zpuisobem dát najevo, co hodlá v ř́zení

30 Rozsudek Nejvyššího správního soudu ze dne 30. 3. 2016, č. j. 10 As 5/2016-36 „I. Pokud správní orgán zjistí, že doručování na elektronickou adresu (〔 19 odst. 3 správního řádu z roku 2004) k urychlení řízení nepřispěje, a neshledá ani žádné jiné důvody opodstatňující takovéto doručování, je oprávněn účastníkovi na požadovanou elektronickou adresu písemnosti nezasílat. Písemnosti tedy doručuje, jako by účastník o doručování na elektronickou adresu vůbec nepožádal. Správní orgán je však v takovém případě povinen účastníkovi řízení sdělit, že mu na jím požadovanou elektronickou adresu doručovat nebude včetně důvodů tohoto postupu (\ 4 odst. 3 a 4 správního řádu z roku 2004).“ 
učinit.“ Popř. Nejvyšší správní soud v rozsudku ze dne 25. 2. 2010, č. j. 5 As 1/2010-70 „Poučovaci povinnost správnich orgámů v rízení, která vedou, je obecně zamèrena na poučeni o procesnich právech a povinnostech (I 4 odst. 2 správníbo rádu z. roku 2004). Do poučovací povinnosti však již̀ nepatrì návod, co by účastník rízeni mèl nebo mobl činit, aby dosábl žádanébo výsledku."

Ustanovení \36 správního řádu pak v odstavci 2 stanoví právo účastníka vyjádřit své stanovisko kdykoliv v řízení a v odstavci 3 je zakotveno právo účastníka vyjádřit se před vydáním rozhodnutí k podkladům pro rozhodnutí. Správní orgán by měl účastníkovi dát na vědomí, kdy hodlá vydat rozhodnutí, aby měl účastník možnost se k podkladům vyjádřit. Viz rozhodnutí Krajského soudu Ústí nad Labem ze dne 25. 6. 2009, č. j. 15 Ca 258/2008-55 „Pokud je účastniku správníbo ř́zeni udèleno správním orgánem poučeni o tom, že procesni práva, keterá mu pro dané správni řžreni náleží, mưže uplatnit po celou dobu trváni tohoto řzeni, aniž by mu pred ukončením dotyčného řzeneni bylo dáno na védomi, k. jakému datu správni orgán hodlá vydat rozhodnuti ve vèci, zakládá to vadu rízeni ve smyslu $\int 76$ odst. 1 pism. c) s. r. s. pro porušeni \} 3 6 \text { odst. } 3 \text { správního rádu z. roku } 2 0 0 4 \text { v návaznosti na cl. } 3 8 \text { odst. } 2 \text { Listiny základních práv } a svobod, které garantuji účastniku správního rízeni možnost prezentovat své stanovisko ke dủkazním prostredkìm shromážděným ve správnim rízeni ve fázi prèd vydáním roz̧odnuti."

V návaznosti na nový občanský zákoník bylo do správního řádu přidáno právo účastníka při jednání se správním orgánem na konzultace s osobou, která mu podle občanského zákoníku může jako podpůrce napomáhat při rozhodování. ${ }^{31}$

Za jedno z obecných práv účastníka $v$ rámci správní řízení lze označit právo být slyšen ve správním řízení. Toto právo má adresátovi zajistit, že nebude jen „objektem řízeni““, ale zejména subjektem řízení, tedy tou osobou, jejíž oprávněné zájmy a práva budou v řízení relevantně posuzovány. Právo být slyšen pak má jeden základní cíl, a to dát adresátu veřejné správy možnost aktivně se zapojit do řízení a vyžadovat od správního orgánu, aby to nejen respektoval, ale zejména na jeho projevy reagoval. K. Styrna - Bartman chápe právo být slyšen jako komplementární soubor práv a přichází se jeho dělením na 5 podkategorií. 1. je zásada účasti na správním řízení. 2. součást práva být slyšen představuje žádost na zahájení, respektive právo podílet se na správním řízení. 3. významnou součást představuje právo účastnit se dokazování. 4. část tvoří právo vyjádřit se $\mathrm{k}$ podkladům a předmětu řízení. 5 podkategorii představuje právo být informován o správním řízení spojená s právem na „právní pomoc“, kterou představuje zejména povinnost správního orgánu poučit účastníka řízení (nejen) o procesních právech. V této souvislosti K. Styrna-Bartman připouští, že je vhodné poskytnout účastníkům (v zájmu

31 KLIKOVÁ, Alena. Procesní práva účastníků v rámci dokazování ve správním řízení. In: ČIČKÁNOVÁ, Daniela, Ivana HAPČOVÁ a Vladislav MIČÁTEK. Sborník príspevkov mez̨inárodnej vedeckej konferencie Bratislavské právnické fórum 2015. 1. vyd. Bratislava: Univerzita Komenského Bratislava Právnická fakulta, 2015, s. 331-334. ISBN 978-80-7160-411-2. 
výkonu dobré správy) i právní rady k meritu věci. ${ }^{32}$ Právo být slyšen podle S. Košičiarové zabezpečuje prosazování principu transparentnosti veřejné správy s tím, že má zabezpečovat informovanost adresáta o správním ř́zení v takovém rozsahu, aby mohl ovlivnit výsledek řízení. Právo být slyšen pak zahrnuje zejména oprávnění uplatňovat návrhy a vyjádřit se $\mathrm{k}$ podkladům řízení. ${ }^{33,34} \mathrm{O}$ právu být slyšen ve správním řízení podrobně pojednává R. Bražina ve své rigorózní práci, který se ve své práci přiklání k chápání tohoto práva komplexně. Chápání práva být slyšen komplexně zahrnuje kromě práva být slyšen v užším smyslu i další významná oprávnění, která je potřebné naplnit, aby mohlo dojít $\mathrm{k}$ materiálnímu naplnění práva být slyšen v užším slova smyslu. Proto zde řadí i otázky spojené s informováním účastníka řízení o zahájení řízení, právo na poučení, právo na informace o postupech správního orgánu, právo na přístup k podkladům řízení a právo být slyšen v užším slova smyslu. Tento nastíněný koncept je v rámci doktríny označován rovněž jako princip transparentnosti. ${ }^{35}$ Autorka se přiklání k názoru R. Bražiny a právo být slyšen považuje za jedno z nejvýznamnějších práv účastníka ve vztahu k právu na spravedlivý proces. O vybraných jednotlivých právech, jež jsou považována za obsah práva být slyšen bylo pojednáno výše.

\section{Ochrana práv účastníků. Problém zneužití práva, zneužití pravomoci a nesprávný úřrední postup}

Jak již bylo zmíněno výše, povinnosti správních orgánů ve vztahu k právům jednotlivých účastníků nejsou vymezeny pouze tak, aby správnímu orgánu umožnily hájit práva a oprávněné zájmy těchto účastníků, ale i tak, že správní orgány by měly pokud možno účinně zamezit nezákonným zásahům do těchto práv, resp. zneužívání těchto práv.

Pokud dochází ze strany účastníků správního řízení či ze strany dotčených osob k záměrným zásahům do subjektivních práv jiných osob, lze uvažovat o zneužití jejich práv. Nelze však přehlédnout, že v mnoha případech se výkon subjektivního práva přímo dotýká i individuálních práv a oprávněných zájmů dalších konkrétních osob. I těmto právům musí správní orgány, ale i soudy poskytnout ochranu.

$\mathrm{V}$ radě prípadů v praxi dochází k porušování povinností správních orgánů nesprávným úředním postupem. Dle judikatury se nesprávným úředním postupem rozumí porušení pravidel předepsaných právními normami pro počínání státního orgánu při jeho činnosti. Nesprávným úředním postupem souvisejícím s rozhodovací činností je např. i nevydání či opožděné vydání rozhodnutí, mělo-li být v souladu s uvedenými pravidly správně

\footnotetext{
32 STYRNA-BARTMAN, Katarzyna. Das Polnische Verwaltungsverfahrensrecht im Lichte der Europäischen Verwaltungsstandard. Disertační práce na Universität Regensburg, 2013, s. 107-113.

33 KOŠIČIAROVÁ, Soňa. Sprámý poriadok. Komentár. Šamorín: Heuréka, 2013, s. 165.

34 BRAŽINA, R. Právo být slyšen ve správnim rǐzení. Seminární práce, PrF MU, Brno, 2016.

35 BRAŽINA, R. Právo být slyšen ve správním rízení. Rigorózní práce, PrF MU. Brno, 2017, s. 75.
} 
vydáno či vydáno ve stanovené lhůtě, případně jiná nečinnost státního orgánu či jiné vady ve způsobu vedení řízení. ${ }^{36,37}$ Znak nesprávnosti úředního postupu je třeba obecně vztahovat k porušení pravidel předepsaných zpravidla procesní normou, jak již bylo uvedeno, a takové porušení se nemusí ve své době jevit samo o sobě nezákonné. ${ }^{38}$ Nesprávný úřední postup může spočívat jak ve vadném konání, tak nekonání oprávněné úřední osoby. Nesprávné konání pak může mít různé př́ičiny. Jednou z př́ičin nesprávného úředního postupu je mnohdy neznalost konkrétního úředníka. Opět zde důležitou neopominutelnou roli hraje lidský faktor. Sice prŕslušné zákony upravující postavení úředníků (např. zákon o úřednících územně samosprávných celkủ ${ }^{39}$ nebo služební zákon ${ }^{40}$ ) stanoví minimální kritéria pro odbornost úředníků a taktéž povinnost úředníků se dále vzdělávat, avšak ne vždy konkrétní úředníci obsáhnout veškerou odbornou materii.

V krajním př́padě můžeme také hovořit o zneužití pravomoci úředních osob při rozhodování. V tomto př́padě se však nejedná o nesprávný úřední postup, ale o úmyslný trestný čin. Zneužití pravomoci je vymezeno trestním zákoníkem ${ }^{41}$ jako trestný čin ustanovením \329. V této souvislosti je nutné podotknout, že se jedná o úmyslné jednání konkrétní úřední osoby, která takto jedná v úmyslu způsobit jinému škodu nebo jinou závažnou újmu anebo opatřit sobě nebo jinému neoprávněný prospěch. Zajisté nelze pod tento trestný čin podřadit běžné pochybění úřední osoby v rámci rozhodovacího procesu, ale pouze ten úřední postup, který budou odpovídat výše uvedené skutkové podstatě.

\section{Závěr}

Závěrem lze uvést, že výše uvedená vybraná práva účastníků ve správním ř́izení jsou provázána s povinnostmi správních orgánů. Ve fázi opatřování podkladů pro vydání rozhodnutí však s právem účastníka navrhovat důkazy na podporu svých tvrzení není spojena povinnost správního orgánu tyto návrhy akceptovat. Povinnost správních orgánů, která koresponduje s tímto právem účastníka, je povinnost řádného odůvodnění postupu správního orgánu. Právo účastníka na řádné poučení o procesních právech je spojeno s povinností správních orgánů toto poučení poskytovat. S právem na informace o správním řízení je také spojena povinnost správního orgánu poučení poskytovat. Účastník řízení má právo na informace jak o zahájení řízení, tak o jeho průběhu. S tímto

36 Rozsudek Nejvyššího soudu ze dne 22. 8. 2002, sp. zn. 25 Cdo 2120/2000.

37 Rozsudek Nejvyššího soudu ze dne 18. 10. 2016, sp. zn. 30 Cdo 3466/2015.

38 IŠTVÁNEK, F. Komentář k ustanovení $₫ 13$ zákona o odpovědnosti za škodu způsobenou př̀ výkonu veřejné moci rozhodnutím nebo nesprávným úředním postupem č. 82/1998 Sb., ve znění pozdějších In: ASPI [právní informační systém]. Wolters Kluwer ČR [cit. 4. 9. 2017].

39 Zákon č. 312/2002 Sb., ve znění pozdějších předpisů, o úřednících územních samosprávných celků.

40 Zákon č. 234/2014 Sb., ve znění pozdějššch předpisů, o státní službě.

41 Zákon č. 40/2009 Sb., ve znění pozdějších přxedpisů. 
právem účastníka konkrétně koresponduje povinnost správního orgánu tyto informace včas poskytovat.

Porušení procesních práv účastníka týkajících se pořizování podkladů pro vydání rozhodnutí nebo týkající se samotného procesu dokazování, lze považovat za natolik závažnou vadu řízení, že může sama o sobě založit důvod pro zrušení rozhodnutí. Toto je hlavně zřejmé nap̌r. v ř́izeních přestupkových, $\mathrm{k}$ nimž se váže větší část judikatury. $\mathrm{V}$ návaznosti na výše popsané, lze konstatovat, že účastníci mají jak v průběhu správního řízení, tak po jeho skončení, řadu zákonných možností a prostředků jak si vymoci dodržení jejich práv. Vždy je však nutné presumovat, že účastníci nemají právní vzdělání, neznají pravidla správního řízení a spoléhají se na poučení ze strany správního orgánu. Když pak poučení schází či není správné nebo přesné, nejsou si tito účastníci vědomi svých procesních práv a tím pádem si nejsou vědomi ani právních možností jak tato práva uplatňovat.

Dle názoru autorky je právní zakotvení jak povinností správních orgánů, tak práv účastníků řízení v současném právním řádu dostatečné a koresponduje s obecně nastavenými požadavky na ochranu veřejných subjektivních práv účastníků. Problémem zůstává pouze lidský faktor, který je ve správním řízení přítomen vždy, nebot’ fakticky rozhodují lidé (oprávněné úřední osoby). Je možné, že bude docházet k porušování povinností zákonem daných správnímu orgánu z důvodu selhání lidského faktoru. I pro tyto situace však existuje řada právních možností pro účastníky jak se bránit a zajistit tak dostatečnou ochranu veřejných subjektivních práv, kdy může být selhání lidského faktoru napraveno. I v prrípadě, že dojde k zásadnímu pochybení správního orgánu, a to absolutnímu nepoučení účastníků řízení, existují jiné instituce, které mohou nap̌r. v rámci kontroly veřejné správy napomoci dotčeným účastníkům se svých práv domoci. Konkrétně se jedná např. o možnost obrátit se na Veřejného ochránce práv, který chrání osoby před jednáním úřadů a dalších institucí, pokud je toto jednání v rozporu s právem, neodpovídá principům demokratického právního státu a dobré správy nebo jsou úřady nečinné. 